\title{
Feedback between zebra mussel selective feeding and algal composition affects mussel condition: did the regime changer pay a price for its success?
}

\author{
HENRY A. VANDERPLOEG*, THOMAS H. JOHENGEN ${ }^{+}$AND JAMES R. LIEBIG* \\ *Great Lakes Environmental Research Laboratory, NOAA, Ann Arbor, MI, U.S.A. \\ +Cooperative Institute for Lake and Ecosystem Research, University of Michigan, School of Natural Resources and the \\ Environment, Ann Arbor, MI, U.S.A.
}

\begin{abstract}
SUMMARY
1. We investigated the role of algal composition on pumping, clearance, assimilation, pseudofaeces and faeces production, feeding time budgets, and condition of zebra mussels from spring to autumn at two sites in Saginaw Bay (Lake Huron) and one site in western Lake Erie. Size-fractioned chlorophyll was used to distinguish between feeding on small $(<53 \mu \mathrm{m})$ and large $(>53 \mu \mathrm{m})$ size fractions, and mussel feeding behaviour was quantified by video observations.

2. Mussel pumping, clearance and assimilation rates varied among sites, particularly during summer, when phytoplankton composition varied considerably among sites. Lowest values were seen at the inner-bay site of Saginaw Bay, low to moderate values at the outer-bay site of Saginaw Bay, and high values at the Lake Erie site. Clearance, pumping and assimilation rates were all highly positively correlated $\left(R^{2}=0.76\right)$ with per cent contribution of flagellates to total algal biomass and negatively correlated with per cent of Microcystis aeruginosa $\left(R^{2}=0.63\right)$. The negative effects on pumping rate (as determined by clearance rate on the $<53 \mu \mathrm{m}$ fraction) of Microcystis, which occurred in the $>53 \mu \mathrm{m}$ fraction, could be mitigated by the presence of flagellates in the $<53 \mu \mathrm{m}$ fraction. 3. Visual observations of mussel feeding showed evidence for poor seston quality during summer negatively affecting feeding rates. High faeces production during times of low assimilation rate was suggestive of poor assimilation efficiency and/or viable gut passage of grazing resistant algae. Long periods of time not filtering by the mussels during some Microcystis blooms and lack of production of a filtering current during one experiment were suggestive of intoxication from microcystin or other secondary compounds.

4. Clearance and feeding rates of the mussels in Saginaw Bay were high during spring and autumn and very low in summer, particularly at the inner-bay site. Condition of the mussels (mass : length ratio) was highest in spring and lowest during summer. This seasonal variation probably reflected high food assimilation rate during autumn and spring and low assimilation rate and reproduction during summer. The condition of mussels throughout the year was higher at the outer-bay than the inner-bay site, reflecting better feeding conditions at the former. Mussel selective feeding may have been responsible for the poor quality of food at the inner bay site; therefore, we postulate that a regime shift in phytoplankton composition promoted by the mussels fed back into lowered condition of the mussels.
\end{abstract}

Keywords: condition, Dreissena polymorpha, feedback, phytoplankton dynamics, self-limitation

Correspondence: Henry A. Vanderploeg, Great Lakes Environmental Research Laboratory, NOAA, 2205 Commonwealth Blvd., Ann Arbor, MI 48104, U.S.A. E-mail: henry.vanderploeg@noaa.gov 


\section{Introduction}

Grazing is recognized as a major driving force of seasonal succession of phytoplankton species, promoting the dominance during summer of a grazing resistant community that includes colonial phytoplankton species too large to ingest, toxic species, and species that survive and benefit from gut passage (e.g. Sterner, 1989). The ability of dreissenid mussels to develop high biomasses in many aquatic systems (e.g. Vanderploeg et al., 2002; Wilson \& Sarnelle, 2002), coupled with their intrinsically high clearance rates (Vanderploeg et al., 2002), makes them important grazers of phytoplankton and recyclers of nutrients that can produce system-wide consequences (Arnott \& Vanni, 1996; Vanderploeg et al., 2001, 2002; Naddafi, Pettersson \& Eklöv, 2007). In Saginaw Bay, as in many other areas of the Great Lakes, dreissenid mussels are the dominant metazoan grazers. At the time of our study, zebra mussel biomass was about 20× that of crustacean zooplankton (Vanderploeg et al., 2002) in Saginaw Bay. The mussels, filtering a broad size range of particles, can greatly reduce phytoplankton populations and greatly increase water clarity, particularly during spring (Vanderploeg et al., 2001, 2002). In addition, selective rejection of Microcystis in pseudofaeces is a likely mechanism promoting toxic Microcystis blooms or dominance in lakes of low to moderate phosphorus (P) concentration invaded by mussels (Vanderploeg et al., 2001; Raikow et al., 2004; Bierman et al., 2005). In inner Saginaw Bay, Microcystis became a dominant member of the summer phytoplankton community after the mussels became established (Vanderploeg et al., 2001; Vanderploeg, unpubl. data). Because of the bulk processing of the filter feeding, toxic or undesirable algae cannot be easily recognized and sorted out from others and rejected in pseudofaeces unless they are large, as is the case of colonial Microcystis in Saginaw Bay, where the phenomenon of selective rejection and bloom promotion was first demonstrated (Vanderploeg, et al., 2001).

A wide variety of clearance rates have been reported for mussels feeding on natural seston (e.g. Reeders, Bij de Vaate \& Slim, 1989; Fanslow, Nalepa \& Lang, 1995; Bastviken, Caraco \& Cole, 1998; Karatayev, Burlakova \& Padilla, 1997; Vanderploeg et al., 2001; Dionisio Pires et al., 2004), and these rates can be considerably lower than those observed on cultured algae in the laboratory (e.g. Kryger \& Riisgård, 1988; Vanderploeg et al., 2001; Dionisio Pires et al., 2004). Therefore, there is considerable uncertainty as to the clearance and feeding rates of zebra mussels in nature and the factors that regulate them. In addition, the quality of the seston as food for mussels may affect carrying capacity by affecting feeding rate and subsequent growth of the mussels. Thus, a negative feedback loop may be postulated between mussel abundance and algal quality for food as mussels selectively leave behind poor quality algae. The low feeding rates observed on toxic Microcystis aeruginosa (Kutzing) from natural seston and on certain isolated laboratory strains suggests such a feedback may be at play (Vanderploeg et al., 2001). It is also possible that other grazing resistant species could have been selected for as well by this dominant grazer. Assuming a dominant grazer does affect phytoplankton community composition, does the shift in algal community regime feed back into lower feeding rate and subsequently poorer condition of the mussels?

As part of a larger study to understand how grazing and nutrient excretion by zebra mussels (Dreissena polymorpha [Pallas]) could promote toxic cyanobacterial blooms (Vanderploeg et al., 2001), we carried out monthly feeding and nutrient excretion experiments on natural seston from two sites - an inner bay and outer bay site - in the strongly P-limited Saginaw Bay of Lake Huron over a 2-year period. Initial work showed that feeding rate and $\mathrm{P}$ excretion were extremely low in the bay, particularly at the inner bay site. To examine behaviour across a larger trophic gradient, we also conducted experiments on mussels from the P-rich Lake Erie and transplanted mussels from one system to another for various time periods. Our objectives were to relate feeding and nutrient excretion to algal composition in order to understand mechanisms of Microcystis bloom promotion and to understand factors that regulate feeding and nutrient excretion. Here, we report on effects of algal composition on mussel feeding. At the same time we also measured seasonal time history of mussel biomass and length, which gave us the opportunity of relating seasonal feeding history to mussel condition. We discuss the possible role of an invader-induced shift in phytoplankton regime affecting their condition and limiting the invader population. 


\section{Methods}

Study sites and collections

Mussels and water from Saginaw Bay came from site SB5, a 3.5-m deep site having a cobble, sand and gravel substrate, within the inner bay (mean depth $=5.1 \mathrm{~m}$ ), hereafter called the inner-bay site, and site SB19, a 4.0-m deep site in the outer bay (mean depth $=13.7 \mathrm{~m}$ ) near Charity Island having a rock and cobble substrate (Nalepa et al., 1995); this site, hereafter called the outer-bay site, represents a shallow area surrounded by much deeper water with sand substrate that was not heavily colonized by mussels. Mussels and water from western Lake Erie were collected in or near Hatchery Bay of South Bass Island, with the mussels collected from cobble substrate. Hatchery Bay, having a mean depth of $5.7 \mathrm{~m}$ is somewhat shallower than western Lake Erie (mean depth of $7.1 \mathrm{~m}$ ). Generally both Saginaw Bay and western Lake Erie are isothermal and well mixed (Vanderploeg et al., 2001).

Temperature, and water samples for chlorophyll- $a$ (Chl-a), particulate organic carbon (POC) and algal composition (Johengen et al., 2000; Vanderploeg et al., 2001) were taken at the Saginaw Bay sites at least monthly from April to November in 1995 and 1996 at 1-m depth using a 5-L Niskin bottle to develop times series of these variables in the bay. The same variables were measured for water samples from Saginaw Bay and Lake Erie site used in mussel feeding experiments as described below.

\section{Collection and handling of mussels}

Dreissena were usually hand collected by divers using SCUBA; however, on some occasions they were collected by benthic dredge or bottom trawl. Rocks with attached clusters of Dreissena were wrapped in moist paper towels and placed in ice chests for transport back to an environmentally controlled room. In hot weather, a tray containing ice or cold gel packs was placed above (but not on) the mussels to keep them cool. Travel time from collection sites to the laboratory was normally $4-5 \mathrm{~h}$, but for some collections from Lake Erie, rocks with attached mussels were collected 1-2 days before transport to the laboratory; these were placed in a 530-L holding tank with a through put of $780 \mathrm{~L} \mathrm{~h}^{-1}$ of Hatchery Bay water pumped from $0.3 \mathrm{~m}$ beneath the surface.

Water collected at the Saginaw Bay sites was pumped into 20-L polycarbonate carboys from a depth $15 \mathrm{~cm}$ above the bottom using a hand-operated diaphragm pump. Water from Lake Erie was taken by pushing carboys beneath the water surface near the middle of Hatchery Bay or in the holding tank. Each 20-L carboy was placed in an ice chest for transport back to the laboratory.

\section{Re-acclimation and general design of feeding experiments}

The size of mussels used $($ mean $=15 \mathrm{~mm}$; range $=14$ $16 \mathrm{~mm}$ ), the 17-h re-acclimation to water from which they came, mussel handling, set-up of feeding experiments, experimental approach and equations followed the standard methods described by Vanderploeg et al. (2001) in which we measured changes in Chl concentration in the water column and the mixed beaker contents of three control beakers and four experimental beakers. This allowed us to calculate both net and gross feeding (Vanderploeg et al., 2001). We typically used four mussels per 2-L beaker, and the feeding duration was typically $2 \mathrm{~h}$. Gentle mixing of beaker contents was provided by bubbling air through a pipette placed in each beaker. We measured changes in $\mathrm{Chl}$ concentration in small $(<53 \mu \mathrm{m})$ and large $(>53 \mu \mathrm{m})$ size fractions. Previous experience showed that colonial algae such as the summer dominant Microcystis showed up primarily in the large size fraction (Vanderploeg et al., 2001).

We calculated (gross) clearance rate $(F)$ for particle removal in each experimental container for both $\mathrm{Chl}$ size fractions and used the size fraction having the highest clearance rate $\left(F_{\text {pref }}\right)$ to estimate pumping rate. Highest clearance rates were almost always found for the small size fraction. Hereafter, we will reserve the use of $F$ to refer to clearance rate for total (sum of both fractions) Chl. The product of pumping rate and 'average' (over time) concentration of $\mathrm{Chl}$ in the water column $\left(\bar{C}_{\text {wc }}\right)$ gave $C h l$ removed; that is, the capture rate $(\mathrm{CR}): \mathrm{CR}=F_{\text {pref }} \times \overline{\mathrm{C}}_{\mathrm{wc}}$. From mass balance of $\mathrm{Chl}$ in the containers we calculated $A$, the assimilation rate, and $F_{A}$, the (net) clearance rate for $\mathrm{Chl}$ assimilated (Vanderploeg et al., 2001). For the first three experiments (April-June 1995) at both the inner-bay 
50 H. A. Vanderploeg et al.

and outer-bay sites, we did not split the seston into size classes. To estimate $C R$ at these times we approximated $F_{\text {pref }}$ by $F$. These experiments showed the highest values of $F$ and $F_{A}$ seen in any of the experiments; thus, we do not expect $F$ to greatly underestimate $F_{\text {pref }}$.

All clearance rates were normalized to ash-free dry weight (AFDW) of the mussels used in the experiments as well as to gill surface area calculated from the gill area to mussel length relationship given by Lei, Payne \& Wang (1996). This latter normalization provided filtering estimates that were independent of mussel size, in contrast to mass that varied by a factor of about 4 for a given length in Saginaw Bay (Vanderploeg et al., 2001).

To calculate $A$ or CR as a per cent of mussel body carbon, we converted Chl- $a$ feeding rate to carbon feeding rate by multiplying $\mathrm{Chl}$ feeding rate by the ratio of seston POC to Chl concentration. AFDW of mussels was converted to carbon content by multiplying AFDW by 0.524 (Nalepa et al., 1993). All feeding rate variables were tested to see if they were significantly different $(P<0.05)$ from zero using a two-tailed $t$-test for all experiments at all times and sites.

\section{Saginaw Bay experiments}

Experiments with natural seston, using the standard re-acclimation and experimental procedure (Vanderploeg et al., 2001), were conducted at approximately monthly intervals at the inner-bay site during AprilNovember in 1995 and 1996. At the outer-bay site, the same frequency was used in 1995, but in 1996 experiments were not performed during August-November. To compare the results of feeding on seston with those for feeding on a highly desirable food, we followed each feeding experiment on inner-bay seston in 1996 with a similar feeding experiment on Cryptomonas ozolini (Skuja), known to be a desirable food for mussels (Vanderploeg et al., 2001). The same mussels, after feeding on seston, were acclimated for $1-2 \mathrm{~h}$ on Cryptomonas suspended in $0.2 \mu \mathrm{m}$ filtered lake water prior to running the Cryptomonas experiment.

\section{Lake Erie and transfer experiments}

Three similar experiments were performed using Lake Erie seston and mussels at different times in 1995-97 (Table 1). To obtain further insight into effects of food quality, we did 'transfer'experiments; after performing feeding experiments with inner-bay or Lake Erie mussels, they were transferred for various acclimation periods to seston from the other system followed by Cryptomonas experiments (Table 1). For acclimation of inner-bay mussels to Lake Erie water, the mussels were transferred to Lake Erie water in the holding tank mentioned above. In the case of Lake Erie mussels, the mussels were acclimated to innerbay water in large aquaria (30-50 L) (Vanderploeg et al., 2001). Standard overnight re-acclimation preceded feeding experiments in all cases.

\section{Direct observation of mussel behaviour}

To directly observe mussel feeding behaviour, a subset of four to six mussels, attached with cyanoacrylate glue by one valve to plastic pedestals, was videotaped in a $3 \mathrm{~L}$ aquarium in the same environmental room where related feeding experiments were performed. They received identical handling and acclimation as the other mussels. The high-resolution video system was mounted on a motor drive and controlled by joysticks outside the environmental room (Bundy et al., 1998). Dark field optics using illumination from above was allowed visualization of the mussels and particles in and near their feeding currents. Video images were captured at a rate of $30 \mathrm{~Hz}$.

Behaviour was observed - usually in lateral view concurrently with the feeding experiments or shortly thereafter. Videotaping was performed for $1-2 \mathrm{~h}$ (usually $2 \mathrm{~h}$ ) with each mussel observed for $15 \mathrm{~min}$ before switching to the next one. In the case of a $2 \mathrm{~h}$ videotaping session, the experimental suspension was changed after $1 \mathrm{~h}$. Behaviour during the first and second hour of 2-h experiments was similar. The water in the videotaping aquarium was not mixed because mixing interfered with visualization of the animal's feeding current and ejection of faeces and pseudofaeces. After transferring the mussels from the acclimation aquarium to the videotaping aquarium, the mussels usually required $<10 \mathrm{~min}$ to start filtering and extend their siphons.

Time budgets on behaviours that interrupted filtering of the mussels were estimated by recording start and stop times of different behaviours. Measured behaviours included excurrent siphon retraction, twosiphon retraction, open but not filtering and pseudofaeces and faeces expulsion. All these behaviours 
Table 1 Conditions in Lake Erie (LE) and between-lake transfer experiments

\begin{tabular}{|c|c|c|c|c|c|c|c|c|c|c|c|}
\hline \multirow[b]{2}{*}{ Date } & \multirow[b]{2}{*}{ Experiment } & \multirow{2}{*}{$\frac{\mathrm{AP}}{(\mathrm{h})}$} & \multirow{2}{*}{$\frac{\text { Temp }}{\left({ }^{\circ} \mathrm{C}\right)}$} & \multirow{2}{*}{$\frac{\mathrm{POC}}{\left(\mathrm{mg} \mathrm{L}^{-1}\right)}$} & \multicolumn{4}{|c|}{ Composition (\%) } & \multicolumn{3}{|c|}{$\bar{C}_{\mathrm{wc}}\left(\mu \mathrm{g} \mathrm{L}^{-1}\right)$} \\
\hline & & & & & Cyan & Green & Diatom & Flag & $<53 \mu \mathrm{m}$ & $>53 \mu \mathrm{m}$ & Total \\
\hline \multicolumn{12}{|l|}{ LE Exp. No. 1} \\
\hline 22 Sept. 1995 & LEM/LES & & 20 & 6.56 & 76.7 & 0.7 & 4.9 & 15.7 & 1.28 & 36.61 & 37.90 \\
\hline \multicolumn{12}{|l|}{ LE Exp. No. 2} \\
\hline 19 July 1996 & LEM/LES & & 25 & 0.51 & 28.4 & 0.7 & 46.3 & 24.0 & 3.13 & 4.89 & 8.02 \\
\hline 19 July 1996 & LEM/Cryptomonas & c. 1 & 25 & 0.15 & & & & 100.0 & & & $2.92^{*}$ \\
\hline \multicolumn{12}{|l|}{ LE Exp. No. 3} \\
\hline 17 Oct. 1997 & LEM/LES & & 16 & 0.28 & 0.0 & 0.1 & 70.3 & 29.6 & 1.02 & 0.30 & 1.32 \\
\hline 17 Oct. 1997 & $\begin{array}{l}\text { LEM/Cryptomonas } \\
\text { (high concentration) }\end{array}$ & c. 1 & 16 & 0.32 & & & & 100.0 & & & $6.41^{*}$ \\
\hline 17 Oct. 1997 & $\begin{array}{l}\text { LEM/Cryptomonas } \\
\text { (low concentration) }\end{array}$ & c. 1 & 16 & 0.04 & & & & 100.0 & & & $1.25^{*}$ \\
\hline \multicolumn{12}{|c|}{ Transfer Ser. No. 1} \\
\hline 30 Aug. 1996 & IBM/IBS & & 21 & 2.04 & 71.2 & 0.9 & 22.3 & 5.6 & 3.38 & 8.87 & 12.26 \\
\hline 30 Aug. 1996 & IBM/Cryptomonas & c. 1 & 21 & 0.31 & & & & 100.0 & & & $5.84^{*}$ \\
\hline 4 Sept. 1996 & LEM/LES & & 25 & 0.28 & 0.0 & 0.2 & 10.8 & 88.9 & 0.99 & 0.12 & 1.11 \\
\hline 4 Sept. 1996 & LEM/Cryptomonas & c. 1 & 25 & 0.10 & & & & 100.0 & & & $1.93^{*}$ \\
\hline 6 Sept. 1996 & LEM/IBS & 41 & 25 & 2.63 & 66.5 & 1.6 & 25.0 & 6.8 & 8.26 & 15.38 & 23.64 \\
\hline \multicolumn{12}{|c|}{ Transfer Ser. No. 2} \\
\hline 19 June 1997 & IBM/IBS & & 19 & 0.41 & 36.1 & 34.2 & 14.6 & 15.2 & 0.38 & 0.22 & 0.60 \\
\hline 19 June 1997 & IBM/Cryptomonas & c. 1 & 19 & 0.16 & & & & 100.0 & & & $2.97^{*}$ \\
\hline 20 June 1997 & LEM/LES & & 19 & 0.18 & 0.0 & 0.0 & 12.8 & 87.5 & 0.36 & 0.02 & 0.38 \\
\hline 24 June 1997 & IBM/LES & 120 & 19 & 0.10 & 0.0 & 0.0 & 4.9 & 95.0 & 0.43 & 0.04 & 0.47 \\
\hline 27 June 1997 & IBM/LES & 168 & 19 & 0.08 & 0.1 & 0.0 & 37.4 & 62.5 & 0.27 & 0.02 & 0.29 \\
\hline
\end{tabular}

Saginaw Bay inner-bay mussels (IBM) and Lake Erie mussels (LEM) were acclimated to Cryptomonas or to seston from the Saginaw Bay inner-bay site (IBS) or Lake Erie (LES) for the acclimation time period (AP) indicated. $\bar{C}_{\mathrm{wc}}$ and POC are respectively average chlorophyll- $a$ and carbon concentrations in the water column during the experiment; Cyan and Flag refer to cyanobacteria (primarily Microcystis) and flagellates respectively.

*Cryptomonas, because of its small size, was found in the $<53 \mu \mathrm{m}$ size category; therefore only total concentration was measured.

completely, or nearly completely, stopped the feeding current, and full two siphon retraction corresponded to valve closure. Partial retractions were included in these categories because they also completely or nearly stopped the feeding current.

The video observations also allowed us to observe the number of faeces and pseudofaeces produced by each mussel. From this, we calculated faeces and pseudofaeces production rates for each experiment as the number (mean $\pm \mathrm{SE}$ ) produced per unit time.

The sum of time spent not filtering in each experiment was determined and expressed as a per cent of the total time budget. For statistical testing of variation among experiments, data were arcsin square-root transformed. High percentages of time not filtering have been associated with mussel stress associated with intoxication or attempts to avoid ingestion of toxic Microcystis in natural seston or certain toxic laboratory strains (Vanderploeg et al., 2001).
Laboratory methods, algal culturing and algal counting

Methods for measuring $\mathrm{Chl}$ and POC in seston and AFDW in mussels are described in Vanderploeg et al. (2001). All Chl concentrations and most other variables were measured with a precision $(S E / \bar{X})<5 \%$. Mussel condition was expressed as the AFDW: length ratio, and the ratio reported here corresponds closely to the weight $(\mathrm{mg})$ of a standard 1.5- $\mathrm{cm}$ mussel (Nalepa et al., 1995) divided by its length (cm). Precision of condition measurements made on mussels (in the four replicate treatments) was typically $<2 \%$. Culture of Cryptomonas followed methods of Vanderploeg et al. (2001).

Lake-water samples for algal counting were preserved in 1\% Lugol's solution and were filtered onto membrane filters for permanent mounting on slides and cell dimensions of the different taxa were converted to cell carbon, the value of interest to us for reporting biomass (Vanderploeg et al., 2001). Our 
52 H. A. Vanderploeg et al.

methods followed those of Fahnenstiel et al. (1998) with the following modifications. After completing the phytoplankton analysis, it was discovered from videotapes of mussel feeding on natural seston that Microcystis biomass had been grossly underestimated for some samples in 1996, when relatively small sample volumes were filtered $(2-10 \mathrm{~mL})$ and Microcystis colonies were very large (thousands of cells/ colony). First and most important, large colonies were often underrepresented on slides when smaller volumes were filtered, thus leading to an undercount. Secondly, when colonies were very large, they contained thousands of cells that obscured each other on the microscope slide making it difficult to estimate all cells present in the colony. Although we counted all cells in a given section (volume) of the colony and then extrapolated cells in this volume to the volume of the whole colony, some undercounting may have occurred. To obtain a better estimation of Microcystis biomass, it was recalculated based on the amount of Chl- $a$ that had been measured in the $>53 \mu \mathrm{m}$ fraction. We assumed that this fraction contained Microcystis colonies plus other large phytoplankton cells or colonies $>53 \mu \mathrm{m}$ in one dimension, and that the percentage of total phytoplankton $\mathrm{Chl}$ in the $>53 \mu \mathrm{m}$ fraction equalled the percentage of total phytoplankton carbon in this fraction. Thus, the corrected Microcystis carbon was simply the phytoplankton carbon in the $>53 \mu \mathrm{m}$ fraction minus the carbon of large non-Microcystis phytoplankton (calculated from phytoplankton counts). It was assumed that all nonMicrocystis phytoplankton had been counted accurately and the total phytoplankton carbon increased the amount equal to the Microcystis carbon increase. Very little difference was seen between counts performed by the standard method and this modified method during 1995, when colonies were smaller and larger sample volumes for slides were filtered.

\section{Correlations of feeding rate variables with environmental variables}

To help evaluate factors that may affect feeding intensity of mussels on natural seston, we did simple correlations between measures of feeding and environmental and seston quality variables that could possibly have an effect on feeding rate. We also did these correlations with ln-transformed clearance rate variables because clearance rate of any consumer is a decreasing function of food quantity above the incipient limiting concentration assuming a type 1 response or a continually decreasing function of food quantity assuming a type 2 response (e.g. Walz, 1978; Vanderploeg, Scavia \& Liebig, 1984; Sprung \& Rose, 1988; Bontes et al., 2007); whatever the functional form, the ln transformation would capture gross features of a clearance rate versus food concentration response for our correlation analyses. For the sake of simplicity and because of results suggestive of a type 1 response for Dreissena (Walz, 1978; Sprung \& Rose, 1988), we will assume a type 1 model and speak of incipient limiting concentration in our analyses below.

The data set we drew upon included all experiments with natural seston reported in this paper as well as an experiment with Lake Erie seston and mussels during a Microcystis bloom in 1995 reported by Vanderploeg et al. (2001). The variables evaluated included temperature, average concentrations of POC and Chl measured over the duration of the experiment, and total phytoplankton biomass (C-based), phytoplankton class (diatoms, greens, colonial cyanobacteria and flagellates) abundance and per cent composition. We aggregated all flagellates (mostly cryptophytes and other small unidentified naked flagellates) to form a single 'desirable' food category because this combined group had no morphological, size, digestive resistance or toxin production defenses to grazers.

\section{Results}

\section{Saginaw Bay experiments and mussel condition}

Temperature and Chl showed strong seasonal variation in Saginaw Bay (Fig. 1) with both inner- and outerbay sites showing very similar patterns. Temperature increased from $6{ }^{\circ} \mathrm{C}$ in spring to a maximum of $25^{\circ} \mathrm{C}$ during summer, and then decreased to $5^{\circ} \mathrm{C}$ in late autumn. Chl concentration showed highest concentrations during the summer, with the inner-bay site having the highest values. Algal composition varied seasonally and between years and sites (Fig. 2). Diatoms (dominants: Cyclotella spp. and Aulacoseira spp.) were an important component during all seasons at both sites. Microcystis aeruginosa was a dominant of the summer community during 1995 and 1996 particularly at the inner-bay site. Thus, the high summer $\mathrm{Chl}$ at this site was associated with Microcystis that dominated the $>53-\mu \mathrm{m}$ fraction. 
Fig. 1 Time histories of chlorophyll- $a$ (Chl-a) concentration and temperature at the inner- and outer-bay sites at Saginaw Bay during 1995 and 1996. Cryp Chl indicates initial Chl- $a$ concentrations in Cryptomonas experiments performed following experiments with inner-bay seston in 1996.

Fig. 2 Seasonal histories of algal composition during 1995 and 1996 at the inner-bay and outer-bay sites at Saginaw Bay.
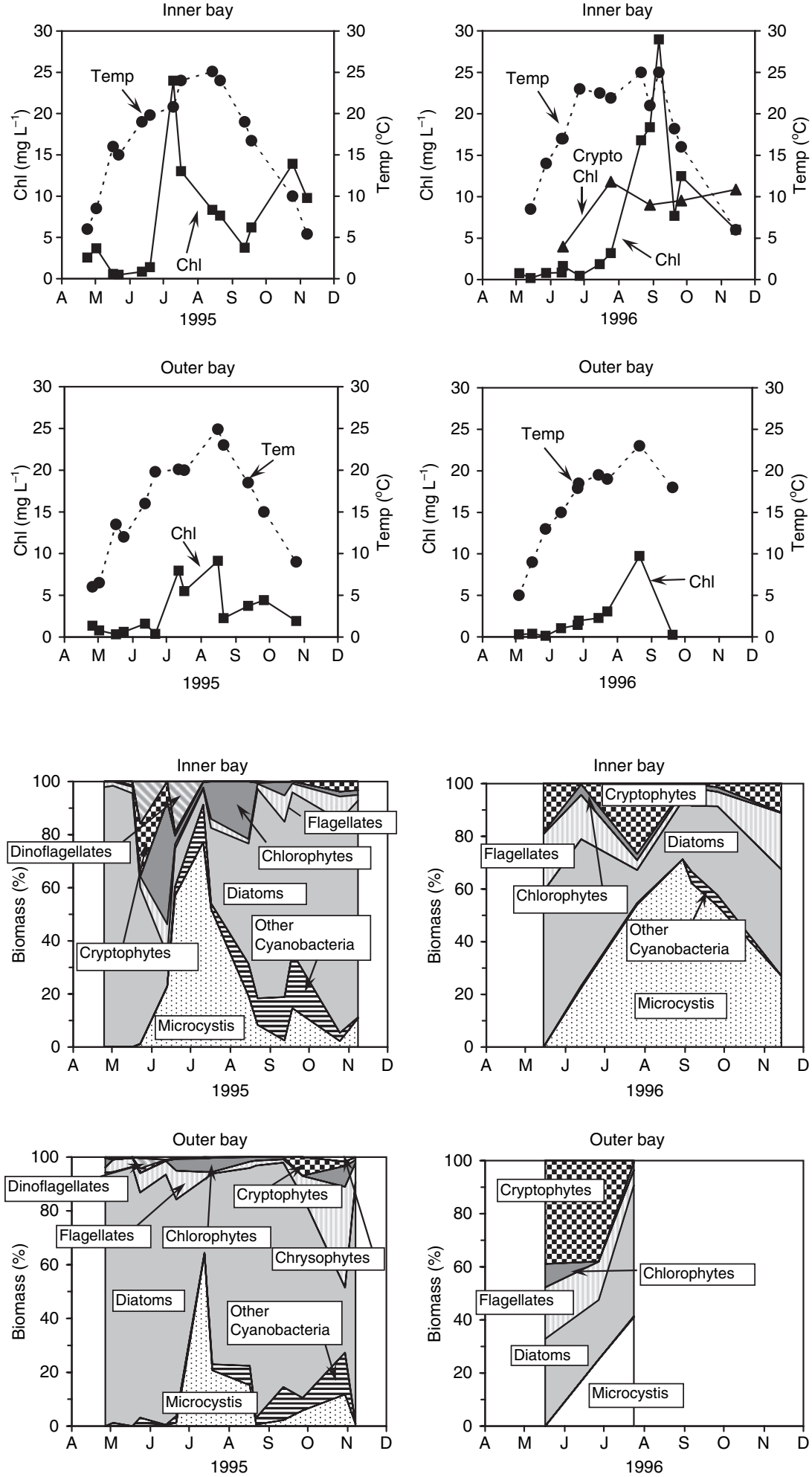

All measures of clearance ( $F_{\text {pref }}, F$ and $\left.F_{A}\right)$ at both sites showed high values in spring, and minimum values during summer (Fig. 3), when Microcystis and diatoms were dominants (Fig. 2). $F_{\text {pref }}$ was higher than $F$, and $F$ was greater than $F_{A}$. In particular, $F_{\text {pref }}$ at the inner-bay site was extremely low (near zero) in 
54 H. A. Vanderploeg et al.
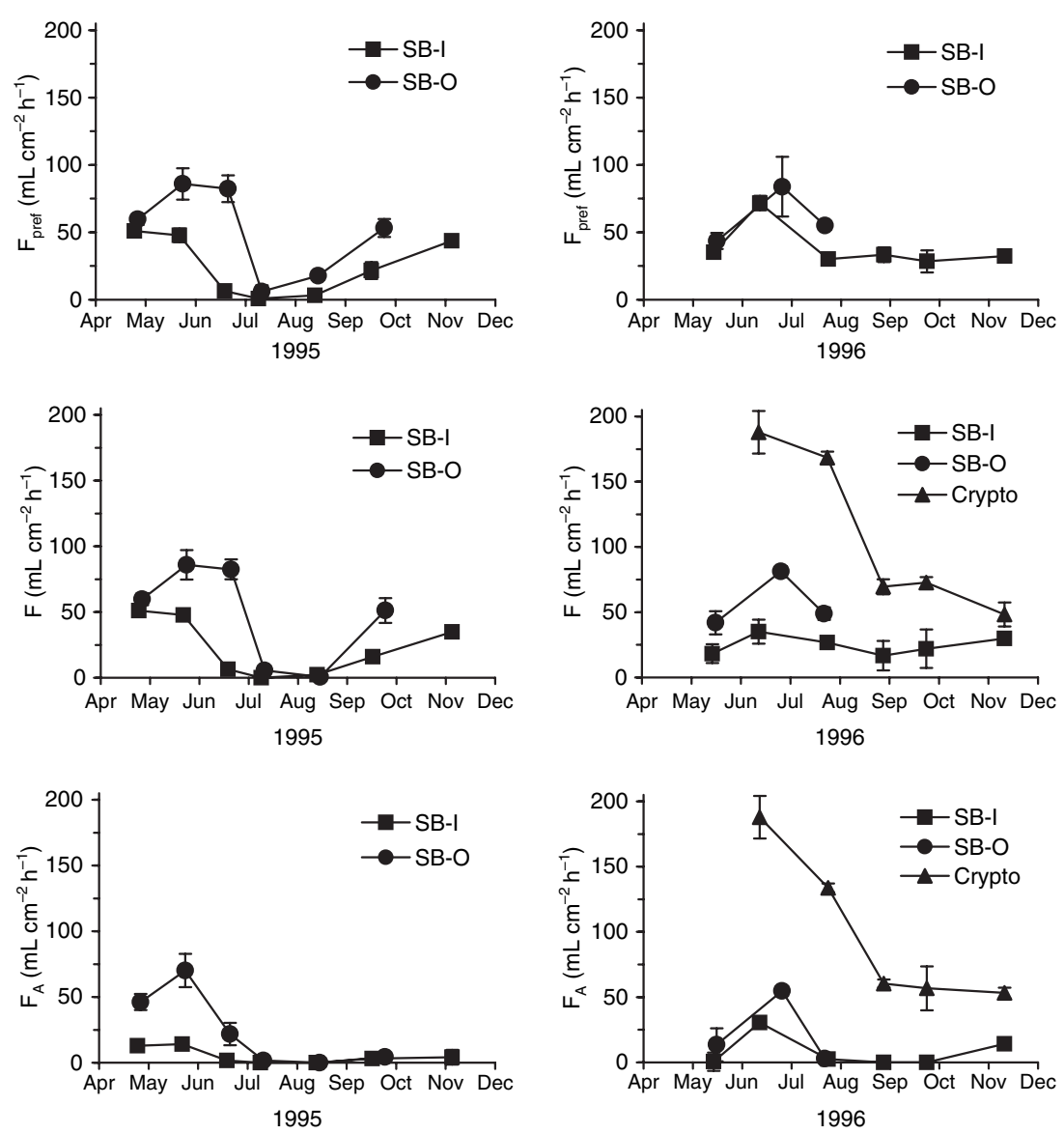

Fig. 3 Seasonal pumping rate $\left(F_{\text {pref }}\right)$, clearance rate $(F)$ and clearance rate for assimilated chlorophyll- $a\left(F_{A}\right)$ on Saginaw Bay seston from inner-bay and outer-bay sites in 1995 and 1996 with a contrast of feeding on Cryptomonas suspensions during 1996.

summer 1995, a time of extreme Microcystis dominance that started early in the summer, compared to summer of 1996. A similar pattern was seen for $F$. At the outer-bay site, where $M$. aeruginosa was not as prevalent, $F_{\text {pref }}$ and $F$ were greater than zero at times during both summers. $F_{A}$ was not significantly different from zero at either site at most times during the summer whether Microcystis or diatoms were dominant. The low clearance and assimilation during summer diatom dominance stands in marked contrast to the high rates seen during diatom dominance in spring.

Compared to rates for natural seston, $F$ and $F_{A}$ were very high when fed Cryptomonas (Fig. 3). These rates varied seasonally, with high rates in late spring that decreased throughout summer and autumn. The reason for this apparent seasonality is discussed in the next paragraph in which we treat $C R$ and assimilation $(A)$ rates.

$\mathrm{CR}$ and $A$ also showed strong seasonal fluctuations (Fig. 4). CR was typically much larger than $A$, and low or zero values of $A$ were seen during summer, particularly at the inner-bay site. Large errors associated with both $A$ and CR during summer result from the product of low but variable values of $F_{\text {pref }}$ (Fig. 3) and high values of $\mathrm{Chl}$ in the environment (Fig. 1). Very high rates (25-30\%) were seen on both CR and $A$ for Cryptomonas, despite its low Chl concentration relative to natural seston during summer (Fig. 1). The lower clearance rates seen on Cryptomonas during late summer and autumn (Fig. 3) may be in large part an artifact of the feeding response saturating (e.g. Walz, 1978; Sprung \& Rose, 1988) at the higher $\mathrm{Chl}$ we provided at this time since $A$ was maximal and relatively constant during this period.

Pseudofaeces production was highest during summer in both years at both sites (Fig. 5). Faeces production also peaked in summer. Although faeces production was higher on a numerical basis, faeces because of their small size relative to pseudofaeces represented a small fraction of mass of pseudofaeces. Generally, despite high values of $\mathrm{CR}$ and $A$, pseudofaeces and faeces production rates of mussels 
Fig. 4 Seasonal capture (CR) and assimilation $(A)$ rates of zebra mussels in Saginaw Bay seston from inner- and outer-bay sites in 1995 and 1996. Results for Cryptomonas suspensions in 1996 are also shown.
Fig. 5 Seasonal pseudofaeces (PFP) and faeces (FP) production rates on Saginaw Bay seston from inner- and outer-bay sites in 1995 and 1996. Results for Cryptomonas suspensions in 1996 are also shown. Lack of data for faeces in June and July resulted from poor visibility of excurrent siphons obtained from the frontal view of the mussels used at these times.
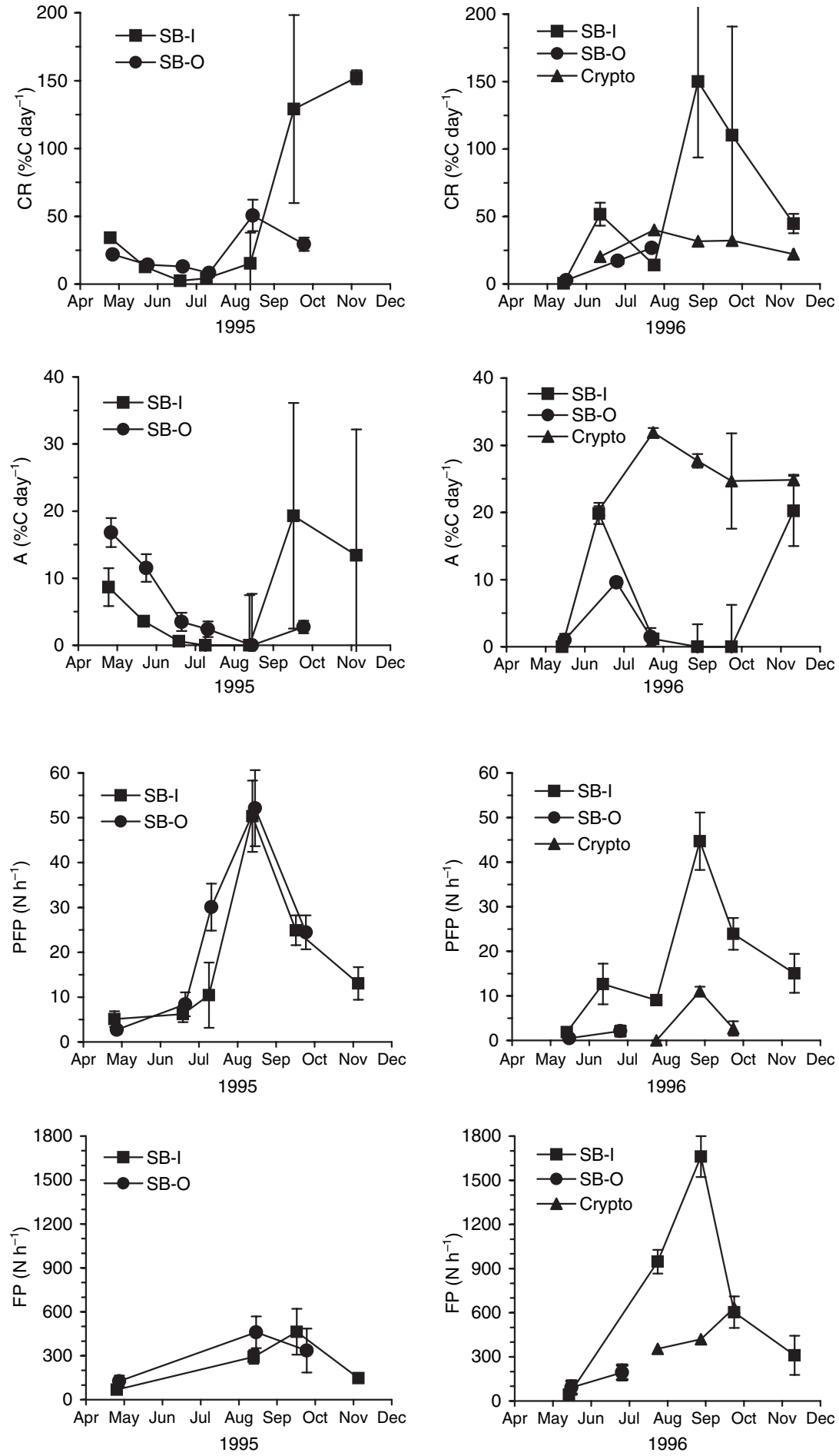

fed with Cryptomonas were much lower than for natural seston.

Visual observations of the mussels suggested they were not under acute stress from their food (or other factors) in Saginaw Bay except on one occasion: the proportion of time spent not filtering was less than $10 \%$ except at the inner-bay site during early July 1995, the time of maximum $M$. aeruginosa abundance (Fig. 2), when it was $46 \%$ (Vanderploeg et al., 2001). 


\section{Lake Erie and transfer experiments}

Experimental conditions were very different among the three Lake Erie experiments and in the two transfer series experiments, both in terms of $\mathrm{Chl}$ concentration and the relative abundance of cyanophytes and flagellates and other algal groups (Table 1). The first experiment captured a Microcystis bloom, whereas the other two Lake Erie experiments had non-bloom conditions with moderate to low Chl. In the first transfer series (late summer 1996), Chl concentration was very much higher at the inner-bay Saginaw Bay site than at Lake Erie, and much of the Chl (mostly Microcystis) was found in the $>53 \mu \mathrm{m}$ size fraction. In the second transfer series (June 1997), Chl concentrations were similar, but the proportion of the algal community consisting of flagellates was larger in Lake Erie water.

The feeding variables in the Lake Erie Experiments were consistent with expected effects of $\mathrm{Chl}$ concen- tration and algal composition as seen from results above. Under the Microcystis bloom conditions of the first experiment, the mussels were actively filtering most of the time (time not filtering $=5.3 \pm 1.9 \%$ ), but nothing was assimilated. $F_{\text {pref }}$ was moderate, but $F$ and $F_{A}$ representing clearance rates on the entire assemblage were not significantly different from zero (Tables $1 \& 2$ ). Because of the moderate $F_{\text {pref }}$ and high Chl, there was a high $C R$ as well as moderate production of faeces and pseudofaeces, and $A$ was not significantly different from zero.

In the second experiment (July 1996), with moderate $\mathrm{Chl}$ concentration and mixture of phytoplankton dominated by diatoms $(46 \%)$ but having significant contributions from both cyanobacteria (28\%; primarily Microcystis) and of flagellates (24\%), all values of clearance were moderately high (18.5$51.0 \mathrm{~mL} \mathrm{~cm}{ }^{-2} \mathrm{~h}^{-1}$ ) despite a fairly high value for time not filtering $(24.4 \pm 8.4 \%)$ (Tables $1 \& 2)$. However,

Table 2 Mean $( \pm$ SE, $n=4)$ clearance rate on the preferred size category $\left(F_{\text {pref }}\right)$, clearance rate $(F)$ on total chlorophyll, clearance rate of chlorophyll- $a$ assimilated $\left(F_{A}\right)$, capture rate $(C R)$, assimilation rate $(A)$, pseudofaeces production rate (PFP), faeces production rate (FP) and fraction of time not filtering (TNF) in Lake Erie and between-lake transfer experiments compared to results in Cryptomonas suspensions

\begin{tabular}{|c|c|c|c|c|c|c|c|c|}
\hline \multirow[b]{2}{*}{ Experiment } & \multicolumn{3}{|c|}{ Clearance rate $\left(\mathrm{mL} \mathrm{cm}^{-2} \mathrm{~h}^{-1}\right)$} & \multirow{2}{*}{$\begin{array}{l}\text { CR } \\
\left(\% \mathrm{Cday}^{-1}\right)\end{array}$} & \multirow{2}{*}{$\begin{array}{l}A \\
\left(\% \mathrm{C} \mathrm{day}{ }^{-1}\right)\end{array}$} & \multirow[b]{2}{*}{$\operatorname{PFP}\left(n \mathrm{~h}^{-1}\right)$} & \multirow[b]{2}{*}{$\mathrm{FP}\left(n \mathrm{~h}^{-1}\right)$} & \multirow[b]{2}{*}{ TNF $(\%)$} \\
\hline & $F_{\text {pref }}$ & $\mathrm{F}$ & $F_{A}$ & & & & & \\
\hline \multicolumn{9}{|l|}{ LE Exp. No. 1} \\
\hline LEM/LES & $43.3 \pm 4.3$ & $3.1 \pm 6.3$ & $2.7 \pm 3.3$ & $260.1 \pm 23.3$ & $17.3 \pm 20.9$ & $79.0 \pm 11.8$ & $281.6 \pm 59.8$ & $5.3 \pm 2.0$ \\
\hline \multicolumn{9}{|l|}{ LE Exp. No. 2} \\
\hline LEM/LES & $51.0 \pm 3.9$ & $28.4 \pm 4.0$ & $18.5 \pm 2.8$ & $23.4 \pm 1.42$ & $8.6 \pm 1.3$ & $162.8 \pm 40.2$ & $160.8 \pm 36.2$ & $24.4 \pm 8.4$ \\
\hline LEM/Cryptomonas & $225.0 \pm 1.5$ & $225.0 \pm 1.5$ & $182.2 \pm 9.5$ & $31.4 \pm 0.1$ & $26.6 \pm 1.4$ & $2.3 \pm 1.4$ & $53.2 \pm 17.5$ & $1.5 \pm 1.0$ \\
\hline \multicolumn{9}{|l|}{ LE Exp. No. 3} \\
\hline LEM/LES & $74.0 \pm 7.9$ & $64.6 \pm 8.0$ & $37.9 \pm 1.6$ & $20.3 \pm 1.8$ & $10.4 \pm 0.6$ & $7.8 \pm 3.2$ & $199.0 \pm 23.6$ & $1.7 \pm 0.5$ \\
\hline $\begin{array}{l}\text { LEM/Cryptomonas } \\
\text { (high conc.) }\end{array}$ & $83.9 \pm 9.4$ & $83.9 \pm 9.4$ & $85.4 \pm 9.7$ & $27.8 \pm 1.4$ & $28.2 \pm 1.4$ & $1.0 \pm 1.0$ & $41.3 \pm 18.0$ & $6.9 \pm 4.3$ \\
\hline $\begin{array}{l}\text { LEM/Cryptomonas } \\
\text { (low conc.) }\end{array}$ & $120.3 \pm 7.2$ & $120.3 \pm 7.2$ & $97.3 \pm 7.22$ & $7.9 \pm 0.2$ & $6.4 \pm 0.2$ & $0 \pm 0$ & $6.2 \pm 4.0$ & $1.5 \pm 1.5$ \\
\hline \multicolumn{9}{|l|}{ Transfer No. 1} \\
\hline IBM/IBS & $33.4 \pm 12.6$ & $16.8 \pm 11.3$ & $-0.1 \pm 0.7$ & $94.5 \pm 32.6$ & $-0.2 \pm 2.2$ & $44.7 \pm 7.2$ & $1661.4 \pm 139.0$ & $1.7 \pm 0.1$ \\
\hline IBM/Crypt & $69.5 \pm 5.7$ & $69.5 \pm 5.7$ & $60.5 \pm 3.1$ & $31.7 \pm 1.7$ & $27.7 \pm 1.0$ & $11.0 \pm 1.0$ & $419.8 \pm 105.0$ & $1.5 \pm 0.4$ \\
\hline LEM/LES & $121.7 \pm 16.8$ & $117.6 \pm 13.8$ & $107.1 \pm 15.1$ & $24.6 \pm 3.8$ & $21.7 \pm 4.6$ & $62.2 \pm 8.4$ & $24.5 \pm 17.2$ & $8.5 \pm 3.8$ \\
\hline LEM/Cryptom & $162.9 \pm 9.4$ & $162.9 \pm 9.4$ & $150.3 \pm 15.6$ & $12.0 \pm 1.3$ & $11.3 \pm 1.9$ & $14.8 \pm 13.1$ & $190.3 \pm 40.8$ & $2.5 \pm 2.2$ \\
\hline LEM/IBS (1.7 days) & $5.7 \pm 4.2$ & $4.4 \pm 5.7$ & $-8.2 \pm 3.8$ & $10.8 \pm 7.7$ & $-15.1 \pm 7.0$ & $39.5 \pm 17.6$ & $97.8 \pm 55.8$ & $14.5 \pm 6.2$ \\
\hline \multicolumn{9}{|l|}{ Transfer No. 2} \\
\hline IBM/IBS & $26.6 \pm 4.6$ & $21.1 \pm 3.3$ & $-5.2 \pm 3.3$ & $10.0 \pm 1.4$ & $-2.0 \pm 1.3$ & $4.4 \pm 1.7$ & $483.8 \pm 138.1$ & $0.5 \pm 0.4$ \\
\hline IBM/Cryptomonas & $77.4 \pm 5.9$ & $77.4 \pm 5.9$ & $80.1 \pm 3.7$ & $11.4 \pm 0.7$ & $11.8 \pm 0.4$ & $1.0 \pm 1.0$ & $7.4 \pm 3.7$ & $0.3 \pm 0.2$ \\
\hline LEM/LES & $146.0 \pm 5.1$ & $140.4 \pm 4.5$ & $90.2 \pm 3.5$ & $19.4 \pm 0.8$ & $12.1 \pm 1.1$ & $5.5 \pm 2.2$ & $134.6 \pm 67.3$ & $0.7 \pm 0.2$ \\
\hline IBM/LES (5 & $125.2 \pm 10.7$ & $123.8 \pm 10.6$ & $58.9 \pm 7.6$ & $12.0 \pm 0.4$ & $5.6 \pm 0.4$ & $19.4 \pm 5.4$ & $285.5 \pm 142.8$ & $1.3 \pm 0.2$ \\
\hline IBM/LES(7 days) & $111.8 \pm 7.4$ & $110.8 \pm 6.8$ & $25.3 \pm 1.5$ & $6.8 \pm 0.6$ & $1.5 \pm 0.1$ & $79.0 \pm 11.8$ & $281.6 \pm 59.8$ & $1.7 \pm 0.6$ \\
\hline
\end{tabular}

In transfer experiments Saginaw Bay inner-bay mussels (IBM) and Lake Erie mussels (LEM) were acclimated to seston from the Saginaw Bay site (IBS) or Lake Erie (LES) for the time period indicated next to the description of the seston. Bold values (shown for all variables except TNF) indicate results different from zero at the $P<0.05$ level, as defined by a 2-tailed $t$-test. 
these rates were not nearly as high as the very high clearances rates (e.g. $F=225.0 \pm 1.5 \mathrm{~mL} \mathrm{~cm}^{-2} \mathrm{~h}^{-1}$; $F_{A}=182.2 \pm 9.5 \mathrm{~mL} \mathrm{~cm}^{-2} \mathrm{~h}^{-1}$ ) for the Cryptomonas treatment. In the experiment with seston approximately two-third of the $\mathrm{Chl}$ assimilated came from the $<53 \mu \mathrm{m}$ size fraction. CR was about $10 \%$ of that seen for the bloom conditions of the first experiment because of lower $\mathrm{Chl}$ concentration, but $A(8.6 \%$ per day) was fairly high relative to other experiments with natural seston. Note that $A$ for Cryptomonas was threefold higher and time not filtering was very low $(1.5 \pm 0.9)$, suggesting a recovery from stress associated with the natural Lake Erie seston. There was high pseudofaeces production and moderately high faeces production with the seston.

In the third Lake Erie experiment, which had low Chl concentration and a phytoplankton community dominated by diatoms $(70 \%)$ and flagellates $(30 \%)$, $F_{\text {pref, }} F$ and $F_{A}$ for LE seston were fairly high (74.0, 64.6 and $37.9 \mathrm{~mL} \mathrm{~cm}^{-2} \mathrm{~h}^{-1}$, respectively) but somewhat lower than in the subsequent experiments with a higher and lower concentration of Cryptomonas (Tables 1 \& 2). In particular, for the Cryptomonas experiment performed at the lower $\mathrm{Chl}$ concentration, which was about the same as the $\mathrm{Chl}$ concentration for natural seston, the difference was more pronounced $\left(F_{\text {pref }}=F=120.3 \mathrm{~mL} \mathrm{~cm}^{-2} \mathrm{~h}^{-1} ; F_{A}=97.3 \mathrm{~mL} \mathrm{~cm}^{-2}\right.$ $\mathrm{h}^{-1}$ ). CR and $A$ for natural seston were intermediate between values for the two experiments with Cryptomonas, and pseudofaeces and faeces production were higher on natural seston. The lower clearance rates observed for the Cryptomonas experiment at the higher Chl concentration and relatively high faeces production point to the high $A$ value as being the maximum value for this temperature, i.e. the Cryptomonas concentration was above the incipient limiting concentration.

In this first transfer experiment series in which Lake Erie mussels fed on seston from both sites and Saginaw Bay mussels fed on Saginaw seston, mussels fed at very low rates on Saginaw Bay seston dominated by cyanobacteria $(66-71 \%)$ and diatoms (22-25\%) - compared to Lake Erie seston - dominated by flagellates $(89 \%)$ - or to Cryptomonas (Tables $1 \& 2$ ). In all of these experiments time not feeding was $<14 \%$. Both inner-bay and Lake Erie mussels had clearance, capture and assimilation rates on inner-bay seston that were not significantly different from zero. In contrast, the Lake Erie mussels fed on Lake Erie seston exhibited high clearance and assimilation rates that approached values seen with Cryptomonas. Pseudofaeces production rates were quite high with inner-bay and Lake Erie seston, and faeces production was very high in the inner-bay mussels/inner-bay seston experiment.

The second transfer experiment series, in which Saginaw Bay mussels fed on seston from both sites and Lake Erie mussels fed on Lake Erie seston, again demonstrated the poor quality of Saginaw Bay seston - dominated by a mixture of cyanobacteria and green algae - as food for mussels relative to Lake Erie seston - dominated by flagellates - or to Cryptomonas (Tables $1 \& 2$ ). $F_{\text {pref, }} F$ and $C R$ were modest in the inner-bay mussels/inner-bay seston experiment, but nothing was assimilated: neither $F_{A}$ nor $A$ was significantly different from zero (Table 2 ). In contrast, inner-bay mussels transferred to Lake Erie seston exhibited very high values of $F_{\text {pref, }} F$ and modest to high values of $F_{A}$. Somewhat higher values of all feeding variables were seen for the mussels from shorter-duration transfer experiment $(120 \mathrm{~h})$, dominated by flagellates $(95 \%)$ than those from the longerduration experiment $(168 \mathrm{~h})$, dominated by a mixture of flagellates $(62 \%)$ and diatoms $(31 \%)$. Lake Erie mussels fed Lake Erie seston exhibited high values for $F_{\text {pref }}, F$ and $F_{A}$. CR, $A$, pseudofaeces and faeces production on Lake Erie seston were generally somewhat lower than in the first transfer series, which reflected lower values of $\mathrm{Chl}$ available in these experiments (Table 1).

\section{Correlation analysis of factors affecting feeding intensity}

Correlations of feeding rate variables with biomass of different algal groups support the importance of flagellates to mussel feeding (Table 3). Negative correlations of clearance rate variables with all measures of algal biomass would be expected from the perspective of feeding rate saturating (and clearance rate decreasing) as algal concentrations increased. Not surprisingly there were strong negative correlations of clearance rates with all measures of seston or algal biomass (Table 3: average POC and $\mathrm{Chl}$ and total phytoplankton biomass) and negative correlations with biomass of all algal groups other than flagellates. Increased algal biomass would not be a constraint on $A$, and here $A$ was only positively correlated with flagellate biomass. 
Table 3 Correlation coefficients for feeding rate variables with temperature, algal composition and quantity of the seston expressed as average concentrations of particulate organic carbon (POC) and chlorophyll (Chl)

\begin{tabular}{|c|c|c|c|c|c|c|c|}
\hline \multirow[b]{2}{*}{ Environmental variables } & \multicolumn{7}{|c|}{ Feeding rate variables } \\
\hline & $F$ & $\ln F$ & $F_{\text {pref }}$ & $\ln F_{\text {pref }}$ & $F_{A}$ & $\ln F_{A}$ & $A$ \\
\hline Temperature & -0.03 & -0.30 & 0.03 & -0.20 & 0.06 & -0.30 & -0.11 \\
\hline Average POC & -0.61 & -0.86 & -0.67 & -0.87 & -0.45 & -0.72 & -0.21 \\
\hline Average Chl & -0.52 & -0.74 & -0.57 & -0.78 & -0.37 & -0.63 & -0.20 \\
\hline Total algal biomass & -0.55 & -0.52 & -0.60 & -0.54 & -0.43 & -0.58 & -0.17 \\
\hline Cyanobacteria biomass & -0.54 & -0.58 & -0.59 & -0.65 & -0.43 & -0.66 & -0.32 \\
\hline Diatom biomass & -0.44 & -0.34 & -0.47 & -0.27 & -0.39 & -0.35 & -0.07 \\
\hline Green biomass & -0.38 & -0.36 & -0.43 & -0.48 & -0.30 & -0.54 & -0.30 \\
\hline Flagellate biomass & 0.17 & 0.21 & 0.20 & 0.26 & 0.24 & 0.24 & 0.45 \\
\hline$\%$ Cyanobacteria & -0.66 & -0.71 & -0.68 & -0.76 & -0.53 & -0.69 & -0.36 \\
\hline$\%$ Diatoms & -0.09 & 0.15 & -0.26 & 0.06 & -0.16 & 0.15 & 0.01 \\
\hline$\%$ Greens & -0.31 & -0.21 & -0.34 & -0.30 & -0.28 & -0.45 & -0.30 \\
\hline$\%$ Flagellates & 0.78 & 0.56 & 0.87 & 0.68 & 0.72 & 0.59 & 0.42 \\
\hline
\end{tabular}

Correlations are shown for untransformed and ln-transformed clearance rate variables. $n=30$ for $F$ and $F_{A}$ and $A ; n=24$ for $F_{\text {pref, }}$ since size-fractioned $\mathrm{Chl}$ were not run on first 6 experiments ( 3 each at the inner- and outer-bay sites in Saginaw Bay during April and May 1995). Numbers in bold indicate correlations that are significant at the 5\% level.

Correlations between feeding rate variables and algal per cent composition data point strongly to a very positive effect of flagellates in stimulating feeding and a negative effect of cyanobacteria in depressing feeding. All measures of clearance rate - including $F_{\text {pref, }}$ which we use as a surrogate for pumping rate were most strongly positively correlated with \% flagellates (Table 3; Fig. 6a) and most negatively correlated with \% cyanobacteria biomass (Table 3; Fig. 6b). It is particularly noteworthy that no algal group other than flagellates had a significant positive correlation, including the diatoms for which the mussels fed upon at high rates during the spring (Saginaw Bay) or autumn (Lake Erie), but low rates during the summer (Saginaw Bay). The Lake Erie data were very important for defining the filtering rate versus per cent flagellate response, since Lake Erie exhibited a broad range of values of this independent variable, including very high values (Table 1; Fig. 6a). $A$ was positively correlated only with $\%$ flagellates, and was significantly negatively correlated with \% cyanobacteria. There was no significant correlation between any feeding rate variable and temperature.

\section{Mussel condition}

Mussel condition varied seasonally and with location (Fig. 7). Because of the extremely tight SE on the individual points, the patterns precisely demonstrate differences with season and site. Highest values were seen in spring and they decreased throughout the summer at both sites. In each year the mass: length versus time curve for the outer-bay site was higher than for its inner-bay counterpart. The curves for both sites were displaced upwards in 1996 relative to 1995, and in 1996 the curve was much higher for the outerthan the inner-bay site. The few values of mussel condition of Lake Erie mussels were generally high and similar to those of outer-bay mussels (Fig. 7).

\section{Discussion}

\section{Feeding}

Except during spring and autumn, clearance and assimilation rates of mussels fed Saginaw Bay seston were very low or zero. Rates were especially low for seston from the inner-bay site. These results are similar to those of Fanslow et al. (1995) who observed lower (gross) clearance rates $(F)$ on total $\mathrm{Chl}$ at this site in summer 1992, when Microcystis and other cyanobacteria were dominant (Vanderploeg et al., 2001) than in 1993, when they were not dominant (Vanderploeg, 2001). In contrast, the rates we observed for Lake Erie seston were generally high, at times approaching values seen for Cryptomonas. At these times flagellates were the dominant phytoplankton group. The observations and the regressions between 

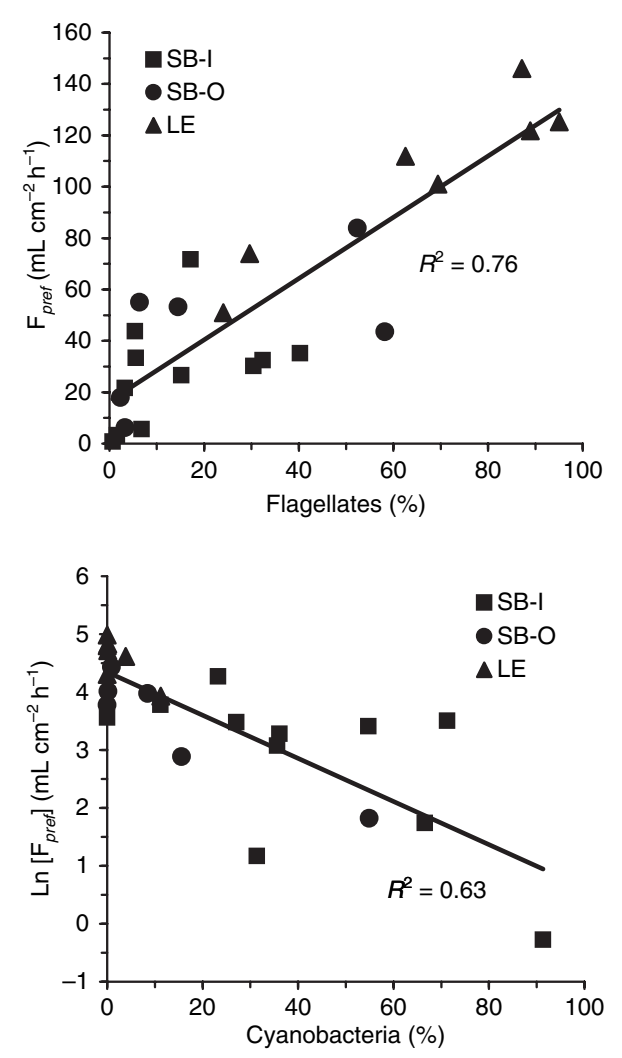

Fig. 6 Regression of pumping rate $\left(F_{\text {pref }}\right.$ versus per cent flagellates in algal community from the Saginaw Bay inner-bay and outer-bay sites and the Lake Erie site (LE).

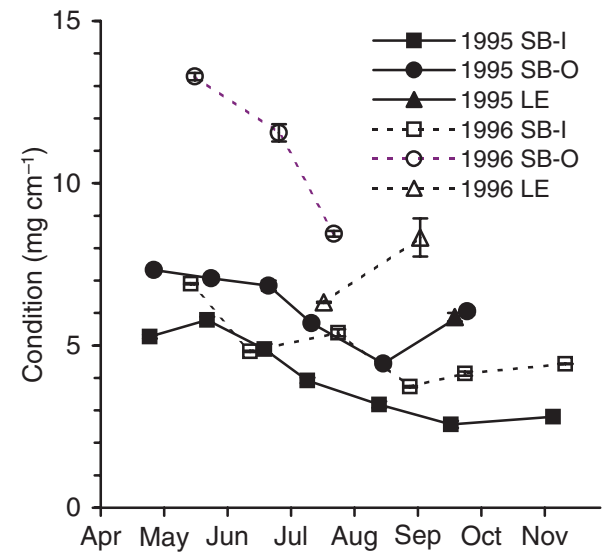

Fig. 7 Mean $( \pm$ SE) seasonal mussel condition (AFDW per length) of mussels used in experiments from inner- and outerbay sites on Saginaw Bay and at locations in Lake Erie (LE) near South Bass Island. Most SE cannot be seen because they are smaller than symbol size.

feeding rate variables and algal composition help account for much of the decreasing order of preference of Lake Erie, outer-bay and inner-bay seston. In general, \% flagellates decreased and \% cyanophytes increased in this sequence (Fig. 6).

Both the strong positive correlation between clearance rate, and \% flagellates in natural seston and the invariably high clearance rates seen after transferring mussels from seston to Cryptomonas, point to flagellates as desirable food that stimulate pumping and allow high clearance and assimilation rates during all seasons. The strong positive correlations with clearance rate variables occurred with \% flagellates rather than flagellate biomass; this suggests they contribute to some overall sensory bulk quality of the food that stimulates pumping. The high correlation of $A$ with both flagellate biomass and with $\%$ flagellates is consistent with a high assimilation (net feeding) rate of this food source. There is no doubt of the importance of flagellates (including cryptophytes) in stimulating pumping $\left(F_{\text {pref }}\right)$ and allowing high assimilation $\left(F_{A}\right.$ and $\left.A\right)$, particularly in summer. The highest value seen for Cryptomonas $\left(F_{A}=182 \mathrm{~mL} \mathrm{~cm}^{-2} \mathrm{~h}^{-1}\right.$ at $\left.25^{\circ} \mathrm{C}\right)$ in the second experiment at Lake Erie, Table 2) is considerably higher than that $\left(90-110 \mathrm{~mL} \mathrm{~cm}^{-2} \mathrm{~h}^{-1}\right)$ reported for Cryptomonas other laboratory cultures of algae by Vanderploeg et al. (2001) and for Chlorella (84-114 $\mathrm{mL} \mathrm{cm}^{-2} \mathrm{~h}^{-1}$ ) reported by Kryger \& Riisgård (1988). The lower clearance rate observed on Cryptomonas by Vanderploeg et al. (2001) is a result of the Cryptomonas being offered at a very high concentration (above the incipient limiting concentration) and was measured at a somewhat lower temperature $\left(20{ }^{\circ} \mathrm{C}\right)$.

Microcystis toxicity may partly explain the strong negative correlation between clearance rate variables and \% cyanobacteria. During the $M$. aeruginosa bloom in the inner bay in July 1995, measured $F_{\text {pref }}$ was zero. Because direct observations showed that the mussels were expelling some pseudofaeces (Fig. 5), $F_{\text {pref }}$ although small, was greater than zero. As noted by Vanderploeg et al. (2001), the pseudofaeces were dominated by loosely consolidated Microcystis colonies when Microcystis was present. It is possible that faeces or pseudofaeces expelled by the mussels remained in suspension and did not settle out before we took the water column samples. Also, the mussels appeared to be under stress, as time not feeding was very high in this case $(46 \%)$. This distress would be consistent with intoxication as a response to expo-

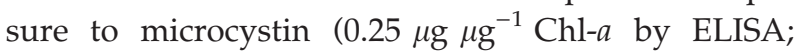


60 H. A. Vanderploeg et al.

Vanderploeg et al., 2001) or another secondary compound produced by Microcystis (Jungmann \& Benndorf, 1994) either as an immediate response or from chronic exposure. Using a strain of Microcystis isolated from Lake Erie (LE-3), Vanderploeg et al. (2001) showed that mussels stopped feeding when LE-3 was presented as small colonies and greatly reduced feeding when presented in an equal biomass mixture with Cryptomonas. Although $F_{A}$ and $A$ were zero at the height of the bloom at the inner-bay site in August 1996, the moderately low $F_{\text {pref }}$ and $F$ values (20$30 \mathrm{~mL} \mathrm{~cm}^{-2} \mathrm{~h}^{-1}$ ) but extremely high CR, pseudofaeces production and fecal production indicated the mussels were very actively processing the seston. Considering the enormous particle processing observed here for no assimilation, it is not surprising $F_{\text {pref }}$ and $F$ were low; that is, mussels probably lowered their filtering efforts to avoid collection of enormous quantities of material that would be rejected as pseudofaeces or be egested (as faeces). Toxin concentration was not measured during this experiment.

Although it is clear that Microcystis itself at times has a negative impact on pumping rate, the presence of small desirable food can in large part overcome the negative Microcystis effects. In the Lake Erie M. aeruginosa bloom of September 1995 (LE experiment no. 1, Table 2), a relatively high $F_{\text {pref }}$ $\left(43.3 \pm 4.3 \mathrm{~mL} \mathrm{~cm}^{-2} \mathrm{~h}^{-1}\right)$ was seen for a relatively low average concentration of $\mathrm{Chl}\left(1.3 \mu \mathrm{g} \mathrm{L}^{-1}\right)$ in the $<53 \mu \mathrm{m}$ size fraction dominated by flagellates, while clearance rate on the high $\mathrm{Chl}\left(36.6 \mu \mathrm{g} \mathrm{L}^{-1}\right)$ in the $>53 \mu \mathrm{m}$ size fraction dominated by M. aeruginosa was zero. In the videotapes of behaviour, Microcystis colonies were obvious in the loosely consolidated pseudofaeces produced. The high $\mathrm{Chl}$ in the $>53 \mu \mathrm{m}$ size fraction resulted in an enormous CR. This conclusion is consistent with the observation of Vanderploeg et al. (2001) that pumping rate further increased when the Lake Erie seston in the first experiment was enriched with the small flagellate (cryptophyte) Rhodomonas. Replacement of the $<53 \mu \mathrm{m}$ size fraction of inner-bay seston with Rhodomonas during the Microcystis bloom of July 1995 resulted in high clearance rate on Rhodomonas, while zero rates were seen for the $>53 \mu \mathrm{m}$ fraction, which was dominated by $M$. aeruginosa. Both the positive effects of flagellates and the avoidance of Microcystis are consistent with recent observations of selective feeding by Naddafi et al. (2007) using delayed excitation spectroscopy to distinguish among algal groups.

The selective feeding here depends on the size difference between colonial Microcystis and desirable flagellates, since as noted above mussels were not able to sort out small colonies of the LE-3 strain of Microcystis from Cryptomonas (Vanderploeg et al., 2001). The low feeding observed during summer when Microcystis was not the dominant phytoplankton and negative or lack of significant positive correlation with any phytoplankton group other than flagellates argues that food quality of phytoplankton other than flagellates was poor during summer. The case of diatoms may provide some insight as they were overall a dominant phytoplankton group across all seasons in Saginaw Bay, and their quality as food varied across season judging by the mussel feeding response. During the spring 1995, diatoms dominated in April and May and very high $F, F_{A}$ and $A$ values were seen at the outer-bay site and moderately high values at the inner-bay site. Thus, diatoms were an excellent food source that stimulated high clearance and assimilation in spring. In contrast, during late summer (August) when they were the dominants (after the Microcystis bloom) at both sites in Saginaw Bay, clearance rates were low and assimilation rates were low or even zero particularly at the inner bay site. Despite this, the mussels were processing seston (77\% of Chl was in $<53 \mu \mathrm{m}$ fraction) as evidenced by the relatively high $\mathrm{CR}$ and there was considerable faeces and pseudofaeces production. These results are consistent with the non-Microcystis component of the phytoplankton being poor quality food or being grazing resistant, including diatoms. In addition to lack of ingestion (and subsequent assimilation) due to pseudofaeces production, there may be the possibility of viable gut passage of not just Microcystis, as has been observed in fish (Lewin, Kamjunkie \& Mehner, 2003), but also other taxa, including green algae for which viable gut passage in zooplankton is a wellknow phenomenon (e.g. Porter, 1976), particularly when nutrient stressed (Van Donk \& Hessen, 1993; Van Donk et al., 1997). It would have been useful to look at the faeces at times of high production, but times of high production were only identified after analyses of the videotapes some time after the experiments. Of the environments examined in this study, the inner bay site was also the most nutrient stressed as measured by $\mathrm{C}: \mathrm{P}$ ratios (T. Johengen \& 
H. Vanderploeg, unpubl. data); therefore, if viable gut passage were an issue, inner-bay algae would potentially be more resistant to digestion. There is no experimental work of which we are aware on the suitability of diatoms as food for mussels or even zooplankton for conditions of nutrient stress. The pumping rate $\left(F_{\text {pref }}\right)$ would suggest that the mussels were not highly motivated to feed to begin with, but this rate could have been biased downward if faeces or pseudofaeces were resuspended.

Temperature did not show up as variable significantly correlated with feeding rate variables. Although temperature does affect clearance and feeding rates (e.g. Walz, 1978; Lei et al., 1996), it was likely overshadowed by the extreme changes in clearance rate $\left(F_{\text {pref }}\right.$ range: $\left.0-146 \mathrm{~mL} \mathrm{~cm}^{-2} \mathrm{~h}^{-1}\right)$ driven by algal composition especially during summer when both zero and highest rates were observed. Although feeding studies have been performed at different temperatures, there has not been careful work on effects of temperature on clearance or assimilation using an optimum food like Cryptomonas (e.g. Walz, 1978; Lei et al., 1996). Observations on CR of microspheres (normalizing results to filter area) and observations on ciliary beat rate suggest a $Q_{10}$ of c. 2 through the range of $8-22^{\circ} \mathrm{C}$ and decreasing at higher temperatures and ceasing at $32^{\circ}$ (Lei et al., 1996). This result is also consistent with observations of clearance rate we have made at very low temperatures $\left(3^{\circ} \mathrm{C}\right)$ in another study (Vanderploeg, unpubl. data) and the observation that for low $\mathrm{Chl}$ concentrations in this study that clearance rates on Cryptomonas were highest at $25{ }^{\circ} \mathrm{C}$. Likely the relatively high clearance rates seen on Saginaw Bay seston during spring (dominated by diatoms with Cyclotella spp. the most common taxon) at low water temperatures $\left(6-12{ }^{\circ} \mathrm{C}\right)$ would have been even higher at higher temperatures.

\section{Consequences of shifting phytoplankton regime}

The seasonal pattern of body mass : length demonstrates that mussels accumulate mass through spring and lose it during summer, a pattern consistent with low assimilation rates during summer and with spawning, which typically occurs in summer in Saginaw Bay and elsewhere (e.g. Nalepa et al., 1995). Although we did not measure feeding in winter, the importance of the autumn to spring period for mussel gonad development (the largest component of body mass in heavy individuals) is witnessed by the large increase in weight to mass for outer-bay mussels between late September 1995 and early May 1996. The much lower seasonal curve of mussel condition observed for the inner bay points to the importance of food quality to mussel growth. Both sites exhibited similar thermal regimes, and overall the Chl concentration at the inner bay was higher than the outer bay (Fig. 1). As we have seen, clearance and assimilation values were lower in response to lower quality food.

The importance of food quality to mussel mass is also underscored by comparisons of mussel mass during the initial invasion of the inner bay with that observed during this study. Autumn surveys of mussel abundance indicated that the mussel population was low but increasing in the bay during 1991 and reached enormous abundance by autumn 1992, overshooting the carrying capacity of the inner bay (Nalepa, Fahnenstiel \& Johengen, 1999; Vanderploeg et al., 2002). Values of mass : length ratio for a $15-\mathrm{mm}$ long mussel for autumn 1991 and 1992 were, respectively, 5.7 and $3.1 \mathrm{mg} \mathrm{cm}^{-1}$. The former value is similar to that observed for the outer bay in this study and the latter value is close to what we observed for the inner bay in the present study. Mussel mass: length started at a high value in spring 1992 (12 $\mathrm{mg} \mathrm{cm}^{-1}$; calculated from Fig. 4 of Nalepa et al., 1995) then decreased to $3.1 \mathrm{mg} \mathrm{cm}^{-1}$ in the autumn. The spring 1992 value is close to what we observed for the outer bay in spring of 1996. With the rapid increase of the mussel population in 1992, Chl increased to $16 \mu \mathrm{g} \mathrm{L}^{-1}$ and Microcystis and other colonial cyanophytes became dominant in summer. There was no recovery of mussel condition during autumn-spring in 1993 as the population crashed, and this was the only year studied that Microcystis did not become a summer dominant in the inner bay (Vanderploeg et al., 2001).

Perhaps it is not surprising that an abundant and selective herbivore would structure community composition this way (e.g. Sterner, 1989), especially where its impact relative to algal growth is high, as in the inner bay (Vanderploeg et al., 2001, 2002). Nalepa et al. (1995) compared masses of 15-mm mussels collected during autumn from a number of environments. The condition observed at the inner bay in our study and in that of Nalepa et al. (1995) were lower than any other environment (range: $3.9-8.1 \mathrm{mg} \mathrm{cm}^{-1}$ ), none of which was dominated 
62 H. A. Vanderploeg et al.

by Microcystis during summer. The comparison of seasonal mass : length ratios and autumn comparisons across other sites demonstrate that the 'regime changer', the mussel, pays a price for changing algal composition.

It is also clear that the influence of zebra mussels as a shaper of algal community composition depends on the ability of the population to acquire body mass during autumn to spring and survive during summer. Moreover, its greatest influence occurs early in the summer before Microcystis and other summer dominants depress filtering and feeding efforts.

\section{Acknowledgments}

We thank Megan A. Agy for help with analysing the videotapes of mussel behavior. Funding for the experiment in Lake Erie was provided by the Lake Erie Protection Fund and the NOAA ECOHAB Program. This is GLERL Publication No. 1478.

\section{References}

Arnott D.L. \& Vanni M.J. (1996) Nitrogen and phosphorus recycling by the zebra mussel (Dreissena polymorpha) in the western basin of Lake Erie. Canadian Journal of Fisheries and Aquatic Science, 53, 646-659.

Bastviken D.T.E., Caraco N.F. \& Cole J.J. (1998) Experimental measurements of zebra mussel (Dreissena polymorpha) impacts on phytoplankton community composition. Freshwater Biology, 39, 375-386.

Bierman V.J., Kaur J., DePinto J.V., Feist T.J. \& Dilks D.W. (2005) Modeling the role of zebra mussels in the proliferation of blue-green algae in Saginaw Bay, Lake Huron. Journal of Great Lakes Research, 31, 32-55.

Bontes B.M., Verschoor A.M., Dionisio Pires L.M., van Donk E. \& Ibelings B.W. (2007) Functional response of Anodonta anatina feeding on a green alga and four strains of cyanobacteria, differing in shape, size, and toxicity. Hydrobiologia, 584, 191-204.

Bundy M.H., Gross T.F., Vanderploeg H.A. \& Strickler J.R. (1998) Perception of inert particles by calanoid copepods: behavioral observations and a numerical model. Journal of Plankton Research, 20, 2129-2152.

Dionisio Pires L.M., Jonker R.R., van Donk E. \& Laanboek H.J. (2004) Selective grazing by adults and larvae of the zebra mussel (Dreissena polymorpha Pallas): application of flow cytometry to natural seston. Freshwater Biology, 49, 116-126.

Fahnenstiel G.L., Krause A.E., McCormick M.J., Carrick H.J. \& Schelske C.L. (1998) The structure of the planktonic food web in the St. Lawrence Great Lakes. Journal of Great Lakes Research, 24, 531-554.

Fanslow D.L., Nalepa T.F. \& Lang G.A. (1995) Filtration rates of the zebra mussel (Dreissena polymorpha) on natural seston from Saginaw Bay, Lake Huron. Journal of Great Lakes Research, 21, 489-500.

Johengen T.H., Nalepa T.F., Lang G.A., Fanslow D.L., Vanderploeg H.A. \& Agy M.A. (2000) Physical and Chemical Variables of Saginaw Bay, Lake Huron in 19941996. NOAA Technical Memorandum GLERL-115, NOAA, Great Lakes Environmental Research Laboratory, Ann Arbor, MI, 39 pp. (NTIS\# PB2000102421/XAB). Available at: ftp://ftp.glerl.noaa.gov/ publications/tech_reports/glerl-115/tm-115.pdf.

Jungmann D. \& Benndorf J. (1994) Toxicity to Daphnia of a compound extracted from laboratory and natural Microcystis spp., and the role of microcystins. Freshwater Biology, 32, 13-20.

Karatayev A.Y., Burlakova L.E. \& Padilla D.K. (1997) The effects of Dreissena polymorpha (Pallas) invasion on aquatic communities in eastern Europe. Journal of Shellfish Research, 16, 187-203.

Kryger J. \& Riisgård H.U. (1988) Filtration rate capacities in 6 species of European freshwater bivalves. Oecologia, 77, 34-38.

Lei J., Payne B.S. \& Wang S.Y. (1996) Filtration dynamics of the zebra mussel, Dreissena polymorpha. Canadian Journal of Fisheries and Aquatic Science, 53, 29-37.

Lewin W.C., Kamjunkie N. \& Mehner T. (2003) Phosphorus uptake by Microcystis during passage through fish guts. Limnology and Oceanography, 48, 2392-2396.

Naddafi R., Pettersson K. \& Eklöv P. (2007) The effect of seasonal variation in selective feeding by zebra mussels (Dreissena polymorpha) on phytoplankton community composition. Freshwater Biology, 52, 823842.

Nalepa T.F., Cavaletto J.F., Ford M., Gordon W.M. \& Wimmer M. (1993) Seasonal and annual variation in weight and biochemical composition of the zebra mussel, Dreissena polymorpha, in Lake St. Clair. Journal of Great Lakes Research, 19, 541-552.

Nalepa T.F., Wojcik J.A., Fanslow D.L. \& Lang G.A. (1995) Initial colonization of the zebra mussel (Dreissena polymorpha) in Saginaw Bay, Lake Huron: population recruitment, density, and size structure. Journal of Great Lakes Research, 21, 417-434.

Nalepa T.F., Fahnenstiel G.L. \& Johengen T.H. (1999) Impacts of the zebra mussel (Dreissena polymorpha) on water quality: a case study of Saginaw Bay, Lake Huron. In: Nonindigenous Freshwater Organisms: Vectors, Biology, and Impacts (Eds R. Claudi \& J.H. Leach), pp. 255-271. Lewis Publishers, Boca Raton, FL. 
Porter K.G. (1976) Enhancement of algal growth and productivity by grazing zooplankton. Science, 192, 1332-1334.

Raikow D.F., Sarnelle O., Wilson A.E. \& Hamilton S.K. (2004) Dominance of the noxious cyanobacterium Microcystis aeruginosa in low-nutrient lakes is associated with exotic zebra mussels. Limnology and Oceanography, 49, 482-487.

Reeders H.H., Bij de Vaate A. \& Slim F.J. (1989) The filtration rate of Dreissena polymorpha (Bivalvia) in three Dutch lakes with reference to biological water quality management. Freshwater Biology, 22, 133-141.

Sprung M. \& Rose U. (1988) Influence of food size and food quantity on the feeding of the mussel Dreissena polymorpha. Oecologia, 77, 526-532.

Sterner R.W. (1989) The role of grazers in phytoplankton succession. In: Plankton Ecology: Succession in Plankton Communities (Ed. U. Sommer), pp. 107-170. SpringerVerlag, Berlin.

Van Donk E. \& Hessen D.O. (1993) Grazing resistance in nutrient-stressed phytoplankton. Oecologia, 93, 503-511.

Van Donk E., Lurling M., Hessen D.O. \& Lokhorst B. (1997) Altered cell wall morphology in nutrientdeficient phytoplankton and its impact on grazers. Limnology and Oceanography, 42, 357-364.
Vanderploeg H.A., Scavia D. \& Liebig J.R. (1984) Feeding rate of Diaptomus sicilis and its relation to selectivity and effective food concentration in algal mixtures and in Lake Michigan. Journal of Plankton Research, 6, 919-941.

Vanderploeg H.A., Liebig J.R., Carmichael W.W., Agy M.A., Johengen T.H., Fahnenstiel G.L. \& Nalepa T.F. (2001) Zebra mussel (Dreissena polymorpha) selective filtration promoted toxic Microcystis blooms in Saginaw Bay and Lake Erie. Canadian Journal of Fisheries and Aquatic Science, 58, 1208-1221.

Vanderploeg H.A., Nalepa T.F., Jude D.J., Mills E.L., Holeck K.T., Liebig J.R., Grigorovich I.A. \& Ojaveer H. (2002) Dispersal and ecological impacts of PontoCaspian species in the Great Lakes. Canadian Journal of Fisheries and Aquatic Science, 59, 1209-1228.

Walz N. (1978) The energy balance of the freshwater mussel Dreissena polymorpha Pallas in laboratory experiments and in Lake Constance. I. Pattern of activity, feeding and assimilation efficiency. Archiv für Hydrobiologie Supplement, 55, 83-105.

Wilson A.E. \& Sarnelle O. (2002) Relationship between zebra mussel biomass and total phosphorus in European and North American Lakes. Archiv für Hydrobiologia, 153, 339-351.

(Manuscript accepted 12 July 2008) 